\title{
REESTRUTURAÇÃO DO CAPITALISMO NO CONTEXTO DAS CIDADES MÉDIAS: REFLEXÕES EM TORNO DA PRECARIZAÇÃO DO TRABALHO EM MOSSORÓ-RN
}

\author{
Cleiton Ferreira da Silva \\ Universidade Estadual Paulista (UNESP) - Presidente Prudente, SP, Brasil \\ Pós-doutorando do Grupo de Pesquisa Produção do Espaço e Redefinições Regionais (GAsPERR) \\ cleitonf4@yahoo.com.br \\ Cláudio Smalley Soares Pereira \\ Universidade de Pernambuco - Petrolina, PE, Brasil \\ Professor Adjunto do Colegiado de Geografia \\ clasmalley@hotmail.com
}

\begin{abstract}
RESUMO
As problematizações evidenciadas neste trabalho refletem as primeiras reflexões a partir de um projeto de pesquisa de maior envergadura que está sendo desenvolvido a respeito da fragmentação socioespacial e urbanização brasileira por um conjunto de pesquisadores no país, denominado "Fragmentação socioespacial e urbanização brasileira: escalas, vetores, ritmos e formas". A ideia proposta aqui está centrada em refletir sobre a reestruturação produtiva e suas implicações sociais, econômicas e espaciais no contexto das cidades médias, analisando especialmente a cidade de Mossoró (uma das cidades integrantes do projeto). Buscamos investigar o impacto desta reestruturação, como resultado e condição de transformação do capitalismo e de modificações substanciais no contexto contemporâneo do mundo do trabalho, com características cada vez mais assentadas sob o funcionamento das tecnologias digitais, configurando o que vem sendo chamado de capitalismo de plataformas, que pode ser exemplificado com os serviços de aplicativos da empresa Bee na respectiva cidade. Empresa de capital local que vem se expandindo por diversas cidades do país através da lógica da "plataformização" e da precarização do trabalhador.
\end{abstract}

Palavras-chave: Globalização da economia. Mundo do trabalho. Tecnologias digitais. Capitalismo de plataformas.

\section{REESTRUCTURACIÓN DEL CAPITALISMO EN LAS CIUDADES MEDIAS REFLEXIONES EN TORNO DE LA PRECARIZACIÓN DEL TRABAJO EN MOSSORÓ-RN}

\begin{abstract}
RESUMEN
Las problemáticas evidenciadas en este trabajo son las primeras reflexiones de un proyecto de investigación de mayor envergadura en desarrollo sobre la fragmentación socioespacial y la urbanización brasileña, por un conjunto de investigadores en Brasil, bajo el título "Fragmentação socioespacial e urbanização brasileira: escalas, vetores, ritmos e formas". La propuesta que se presenta se centra en reflexionar sobre la reestructuración productiva y sus implicaciones sociales, económicas y espaciales en el contexto de las ciudades medias, analizando especialmente la ciudad de Mossoró (que forma parte del proyecto). Buscamos investigar el impacto de esa reestructuración, como resultado y condición de transformación del capitalismo y las modificaciones sustanciales en el contexto contemporáneo del mundo del trabajo, com características cada vez más asentadas bajo el funcionamiento de las tecnologías digitales, configurando lo que viene denominándose como capitalismo de plataforma, que puede ser ejemplificado con los servicios de aplicativos de la empresa Bee en esa ciudad. Empresa de capital local que viene expandiéndose por diferentes ciudades del país a través de la lógica de "plataformización" y de precarización del trabajo.
\end{abstract}

Palabras clave: Globalización de la economía. Mundo de trabajo. Tecnologías digitales. Capitalismo de plataformas. 


\section{INTRODUÇÃO}

A acumulação flexível resultou da redefinição estrutural do capitalismo e da crise dos anos 1970. Mudanças substanciais foram provocadas em diversos setores da sociedade, potencializando uma acumulação do capital que teve como características a ascensão do mercado em detrimento do papel do Estado, a privatização de empresas estratégicas públicas, a minimização da ação do setor público na garantia dos direitos básicos e na prestação de serviços essenciais. Ao mesmo tempo, pode ser destacado o aprofundamento de um sistema financeiro global, combinado com a dispersão geográfica das grandes corporações e a redefinição nas relações do trabalho. Todos estes fatores funcionaram como mecanismos que potencializaram as desigualdades socioespaciais em escala global, fato presente, também, no Brasil.

Com a reorganização produtiva, o mundo do trabalho foi significativamente impactado, através da complexificação das relações de produção, da automação dos meios produtivos, da perda de direitos historicamente constituídos, resultando na precarização da classe trabalhadora, tornando-a sistematicamente em subempregados, subcontratados, terceirizados ou simplesmente trabalhadores informais, como atestam as transformações históricas do capitalismo e são sublinhados pelas pesquisas de Marx (2001; 2011), Harvey $(2006 ; 2016)$ e Dardot e Laval (2016).

É possível perceber que tais processos fazem parte do atual contexto do capitalismo, e que no Brasil a face mais perversa da globalização do capital tem sido posta em prática nas últimas décadas. A formação socioespacial brasileira (SANTOS, 1978) está inserida nas dinâmicas do capitalismo global em processo constante de reestruturação que significa, na realidade brasileira, a destruição das conquistas trabalhistas, sociais e, o desmonte do Estado. O capital utiliza-se dos mecanismos mais modernos para a extração do mais-valor, incorporando os setores mais diversificados do trabalho, logo, os conflitos se radicalizam ainda mais, com lutas cada dia mais extremadas.

As reflexões aqui presentes, as quais estão centradas na relação entre precarização do trabalho no contexto do capitalismo brasileiro e sua inserção nas cidades médias, em especial a cidade de Mossoró, dizem respeito aos primeiros resultados de uma pesquisa mais ampla em andamento que vem sendo desenvolvida no âmbito de um projeto que logra compreender a urbanização brasileira, suas heterogeneidades e os processos de fragmentação socioespacial a ela atrelados ${ }^{1}$. Dentre as diversas dimensões de estudo presentes no projeto (habitar, lazer, consumir, trabalhar e mobilidade), o foco recai, nesse artigo, na dimensão trabalhar. Esclarece-se, entretanto, que dado o andamento da pesquisa, a proposição aqui apresentada, se constitui muito mais como primeiras aproximações e reflexões em torno do tema supracitado.

Desta forma, a reestruturação produtiva e espacial, e seus impactos na urbanização e nas cidades médias, é analisada no primeiro tópico deste artigo, a partir de Santos (1978), Soja (1993; 2010), Lefebvre (2000; , Corrêa (2007), e Silveira (2015); em seguida, nos propusemos a debater e compreender a lógica das transformações no mundo do trabalho, atreladas às novas tendências presentes no Brasil em sua precarização em Marx (2001), Antunes (2000; 2018), Harvey (2006), Mészáros (2011) e Standing (2015), por exemplo, por fim, analisa-se empiricamente a empresa Bee, que opera por meio da lógica da "plataformização" em Mossoró ${ }^{2}$ e que, com pouco mais de dois anos de atuação, atingiu 24 estados do Brasil, com mais de 70 franquias, representando, portanto, a tendência recente do capitalismo por meio do aumento da precarização do trabalhador, sustentando pelos trabalhos de Abilio (2017), Fontes (2017) e Slee (2017).

Neste contexto, a metodologia e a sistematização deste artigo basearam-se inicialmente em um levantamento das discussões teórico-metodológicas que envolvem a precarização do trabalho, a reestruturação do capitalismo na periferia do sistema e o processo de urbanização, tendo a produção

\footnotetext{
1 Trata-se do Projeto Temático Fragmentação socioespacial e urbanização brasileira: escalas, vetores, ritmos e formas (FragUrb). Sob o financiamento da Fundação de Amparo à Pesquisa do Estado de São Paulo (FAPESP), Processo: 18/07701-8 e coordenado pela Profa. Dra. Maria Encarnação Beltrão Sposito.

${ }^{2}$ A cidade é considerada um entreposto importante do nordeste brasileiro, localizada a oeste da capital Natal, possui atividades econômicas diversificadas como a extração de petróleo pela Petrobrás, extração de sal e desenvolvimento da fruticultura irrigada, através de investimentos públicos (ROCHA, 2005; ELIAS; PEQUENO, 2010; PONTES, 2012). Todavia, há forte retração de investimentos no setor petrolífero e redução do trabalho formal, com aumento substancial da informalidade e precarização nos últimos anos, conforme detalharemos na última parte deste artigo.

Caminhos de Geografia

Uberlândia-MG

v. 22 , n. 80

abr./2021

p. $34-52$

Página 35
} 
do espaço como perspectiva teórica. Um primeiro trabalho de campo foi realizado na cidade de Mossoró entre os dias 19 e 26 de outubro de 2019. Dentre as diversas incursões que foram realizadas nestes dias, as quais dizem respeito à realização do projeto de pesquisa já mencionado, foram realizadas diversas entrevistas, dentre elas, a entrevista informal e focalizada ${ }^{3} \mathrm{com}$ a empresa Bee Delivery, intentando compreender as novas formas do trabalhar, de mobilidade e do viver na cidade média brasileira. Importa mencionar, também, o levantamento de referencial sobre a cidade analisada, bem como a sistematização de dados secundários de órgãos oficiais a respeito da atual situação do emprego no espaço urbano e a utilização de jornais e notícias da imprensa como fonte de pesquisa.

Como se trata de uma pesquisa em andamento, a intenção é problematizar e sistematizar, de uma maneira mais clara, as novas formas do trabalhar no contexto das cidades médias. Parece claro que os estudos que envolvem a temática do trabalho em relação à cidade ainda se concentram majoritariamente nos espaços metropolitanos e, portanto, busca-se contribuir um pouco na direção de debater o trabalho nas cidades médias no contexto brasileiro. Esse artigo trata-se, assim, de uma primeira tentativa de travar esse debate.

\section{REESTRUTURAÇÃO ESPACIAL E URBANIZAÇÃO CONTEMPORÂNEA: BREVES APONTAMENTOS PARA A COMPREENSÃO DO TRABALHO EM CIDADES MÉDIAS}

As ciências sociais já há algum tempo vêm manifestando interesse pelo processo de urbanização e suas consequências sociais, políticas e culturais. Muito foi escrito sobre a vida social na cidade, o consumo, as formas de comércio, espaços públicos urbanos etc. No que se refere especificamente a maneira de se compreender as dinâmicas urbanas, tem-se observado que a transformação do mundo do trabalho se apresenta, cada vez mais, como um componente que dificilmente pode ser compreendido sem a consideração, igualmente importante, das transformações espaciais urbanas e suas relações com a dinâmica do capitalismo. A discussão neste artigo dialoga com a necessidade de análise da urbanização contemporânea como espaços que efetivam fluxos tecnológicos, os quais, por sua vez, contribuem com a precariedade das relações trabalhistas de forma mais intensiva no capitalismo periférico, como é o caso do Brasil.

Isso coloca em destaque a necessidade de se levar em consideração que as transformações do mundo do trabalho não acontecem em um espaço abstrato e sem concretude histórica; pelo contrário, como frisou Santos (1978, p. 161), na mesma linha de raciocínio de Lefebvre (2000), "o ato de produzir é igualmente o ato de produzir espaço", o que traz o trabalho para o centro da discussão. Mas, é importante, ainda, frisar que além de produto, o espaço é, também, condição e meio, lugar da reprodução das relações de produção e, portanto, produto do trabalho humano, social, distinto, assim, da natureza (LEFEBVRE, 2000; CARLOS, 2011). Difícil não perceber aí influência direta de Marx (2011), para quem:

A natureza não constrói máquinas nem locomotivas, ferrovias, telégrafos elétricos, máquinas de fiar automáticas etc. Elas são produtos da indústria humana; material natural transformado em órgãos da vontade humana sobre a natureza ou de sua atividade na natureza. Elas são órgãos do cérebro humano criados pela mão humana; força do saber objetivada (MARX, 2011, p. 589).

É de extrema importância insistir no fato de que a historicidade do capitalismo e suas transformações contemporâneas têm alterado espaços, urbanos e rurais, e modificado a vida de milhões de pessoas. Para o interesse neste artigo, são a reestruturação do capitalismo e o reflexo nos espaços urbanos que serão examinados, em particular as cidades médias brasileiras.

Já há uma extensa bibliografia sobre o tema das cidades médias. Essa bibliografia, sistematizada e discutida por Sposito (2010) mostra que as transformações do capitalismo e do processo de reestruturação econômica e espacial, fomentou olhares para as dinâmicas urbanas além das metrópoles. Os estudos envolvendo rede urbana, pós-fordismo e acumulação flexível demandaram, assim, que para se compreender o território e a produção do espaço, seria necessário incluir as

\footnotetext{
${ }^{3}$ A partir de Gil (2011) realizamos a entrevista informal e a focalizada. Enquanto a primeira tem um caráter exploratório e aproxima o pesquisador do problema pesquisado, a segunda, enfoca um tema específico, sendo permitido ao entrevistado falar livremente do assunto, mas com esforço do entrevistador em voltar ao foco, quando percebe que o entrevistado começa a desviar-se. Entendemos, portanto, que as duas técnicas não se excluíram, mas complementaram-se neste trabalho.
}

$\begin{array}{lllll}\text { Caminhos de Geografia } \quad \text { Uberlândia-MG } & \text { v. 22, n. } 80 \quad \text { abr./2021 } & \text { p. 34-52 } & \text { Página } 36\end{array}$


cidades médias no contexto da problemática urbana e espacial que emergiu com as crises capitalistas das últimas décadas.

As cidades médias no Brasil e no mundo ganharam espaço nos debates em torno da problemática urbana. Hoje em dia é bastante comum encontrar análises que focam nestas cidades visando compreender as manifestações espaciais e sociais de diversos fenômenos, tais como a reestruturação econômica, as desigualdades socioespaciais e as novas formas de consumo. Esses estudos (SPOSITO, 2007; SPOSITO, 2010; MELAZZO 2014; SILVEIRA, 2015), confirmam que "os impactos da globalização, geograficamente desiguais, não se limitam ao que se denomina cidades globais ou mundiais, mas vem afetando, em graus diferentes, virtualmente a todos os lugares do planeta" (SOJA, 2010, p. 214 - tradução nossa).

Em uma linha de raciocínio semelhante à de Soja (2010), Silveira (2015) chama a atenção para levarmos em conta a diversidade de manifestações do fenômeno urbano em suas dimensões espaciais e temporais. Em um país como o Brasil, com um vasto território e bastante heterogêneo, não seria interessante, do ponto de vista da dinâmica do capitalismo em suas manifestações de universalidade e singularidade, reduzirmos o nosso olhar somente aos espaços metropolitanos e suas dinâmicas e processos. Nesse sentido,

[...] é preciso insistir na relevância dos estudos sobre a diversidade de manifestações do fenômeno urbano para evitar o risco de olhar apenas as metrópoles na atual divisão territorial do trabalho e de formular uma interpretação ahistórica da formação socioespacial e dos sistemas urbanos (SILVEIRA, 2015, p. 180).

As cidades médias, assim nomeadas por ser um estrato da rede urbana que faz conexão e intermediação com outros estratos (SPOSITO, 2010), exercem papéis econômicos e políticos dignos de análise. Se nas décadas passadas, quando dos primeiros estudos sobre essas cidades, o foco recaía nas relações entre cidade e região, atualmente, no contexto do capitalismo pós-fordista e flexível, estas cidades passaram a manter relações e conexões para além de suas regiões imediatas e de influências, modificando as hierarquias anteriormente estabelecidas e repercutindo empiricamente em todas as cidades, direta ou indiretamente. Daí que novas redes urbanas surgem em razão das novas demandas produtivas e de consumo do capitalismo contemporâneo, redefinindo os papéis das cidades médias e da própria lógica da urbanização (SPOSITO, 2010). No caso brasileiro isso também é importante, posto que nas últimas décadas, com as políticas regionais de desenvolvimento e um conjunto de políticas econômicas e sociais, novos agentes econômicos passaram a escolher esses espaços urbanos como lócus de operações, conforme assinalou Araújo (2013).

Essa realidade enseja que novos estudos sejam realizados visando compreender como as cidades médias brasileiras e a urbanização no território nacional mudaram nas últimas décadas. Essas transformações, por sua vez, têm nexos claros com as dinâmicas econômicas e políticas em múltiplas escalas geográficas. No contexto do desenvolvimento geográfico desigual e das reestruturações espaciais (SMITH, 1988; SOJA, 1993; HARVEY, 2006), o processo de urbanização e a produção do espaço urbano ganham uma centralidade importante, isto é, tanto a produção da cidade como a das redes e sistemas urbanos se apresentam como elementos centrais para a reprodução do capitalismo no atual contexto neoliberal e financeiro.

O que é importante na análise é observar que tais cidades, no mundo contemporâneo, desempenham papéis e funções importantes e que estão inseridas no complexo processo de produção do espaço. Isso significa dizer que múltiplas escalas estão envolvidas nas dinâmicas da urbanização e na produção dos espaços urbanos das cidades médias, o que se torna mais eloquente em um contexto de "revolução tecnológica e das comunicações" (HARVEY, 2006), dando uma nova qualidade ao espaço produzido, hoje. A famosa conceituação de Santos (1996), segundo a qual a época contemporânea produz um meio geográfico próprio, chamado por ele de "meio técnico-científicointernacional", permite aproximar as relações entre globalização capitalista, urbanização e novas formas de trabalho, posto que os meios técnicos atuais permitem uma importante mutação no campo do trabalho associado à reestruturação produtiva (como ver-se-á no próximo item deste artigo) o que traz à tona as complexas interações espaciais que atravessam as cidades médias e as contradições que nela se reproduzem. Tal raciocínio nos leva ao encontro de Corrêa (2007), que escreveu:

Admite-se que a cidade média apresente interações espaciais intensas, complexas, multidirecionais e marcadas pela multiescalaridade. Mais do que isso, essas interações espaciais são, em grande parte, controladas pela elite da cidade. Por meio dela, a cidade média conecta-se à rede global de cidades e interações, ainda que outras interações sejam controladas por grupos externos (CORRÊA, 2007, p. 30). 
Esses resultados da reestruturação espacial foram teorizados por Soja (1993) em nível mais global, e suas repercussões no Brasil foram por demais evidentes, ainda que não na mesma velocidade que em outros países e mesmo com diferenças qualitativas e quantitativas entre cidades e regiões na formação socioespacial brasileira. A reestruturação espacial refere-se a um conjunto de transformações que vem ocorrendo no plano da sociedade capitalista na sua dimensão espacial desde mais ou menos a virada dos anos 1960-1970. Muitos autores, inclusive, já trataram desta temática, e grosso modo, a reestruturação espacial envolve uma miríade de processos que do ponto de vista teórico e prático sinalizam, de um lado, para uma transformação na própria dinâmica do modo de produção capitalista (veja-se, por exemplo, o papel do capital financeiro em relação às outras frações do capital) e, por outro, a necessária espacialidade destes fenômenos. Aqui recorre-se a Harvey (2006) e Soja (1993), para exemplificar a desindustrialização, a nova lógica espacial da indústria, as mudanças no mercado de trabalho e na dinâmica do emprego, os papéis dos Estado no sistema mundial e o consumo na realização do valor com sua ascensão, até certo ponto, central da dinâmica contemporânea da acumulação do capital.

Porém, essa reestruturação espacial tem, também, uma especificidade urbana que traz a urbanização para o centro dos debates teórico e políticos contemporâneos. Isso não significa, evidentemente, que o campo tenha desparecido, já que as novas lógicas do capital redefinem os espaços em um contexto de nova divisão territorial do trabalho que, em muitos casos, especializa os lugares em termos de produção agrícola. De todo modo, como atestam muitos autores, dentre eles Santos (2008), Harvey (2006), Soja (1993) e Smith (1988), a urbanização, enquanto processo, e o urbano enquanto modo de vida e fenômeno social característico da contemporaneidade, assumem uma proeminência. Daí ser possível compreender que esta reestruturação espacial pode ser analisada em uma dupla escala: na escala da cidade e na escala da rede urbana. Por isso Sposito (2007), busca compreender o contexto da terceira revolução industrial e do capitalismo contemporâneo a partir do processo de reestruturação urbana (a escala da rede urbana e dos sistemas urbanos) articulado dialeticamente com a reestruturação da cidade (a escala do que se convencionou chamar de "espaço intra-urbano"), destacando que, nesse bojo, as cidades médias se reposicionam no âmbito da produção do espaço e da acumulação do capital, beneficiadas por processos que interligam de maneira mais eficaz, veloz e precisa estas cidades com outras redes urbanas e sistemas urbanos distintos não mais somente de forma hierárquica, mas também em rede.

Esse desenvolvimento geográfico desigual por meio da seletividade espacial (SANTOS, 1996) mostra, dentre outras coisas, que os espaços urbanos foram alçados a nós da globalização capitalista contemporânea, tendo as cidades médias papéis a serem desempenhados, em alguns casos no âmbito produtivo e em outros nos âmbitos comercial e de serviços, configurando, assim, a terciarização que é característica da economia contemporânea (SINGER, 1979; SANTOS, 2008; HARVEY, 2006). É nesse contexto que o processo de precarização do trabalho e a ampliação da pobreza e da desigualdade se observam, sobretudo após a década de 1990, apesar do período lulista ter deixado um legado, até certo ponto, positivo em termos de políticas sociais e de mobilidade social (SINGER, 2012; POCHMANN, 2014).

Em um estudo a respeito dos impactos da reestruturação produtiva nas cidades médias do Nordeste do Brasil, Pontes (2012) mostra como as mudanças no sistema produtivo global incidiram no espaço regional e nas cidades, redefinindo as lógicas de produção espacial em relação às necessidades do capital. Nesse bojo, o processo de modernização capitalista, que afetou decisivamente as lógicas e os processos espaciais, bem como as dinâmicas de produção e consumo, modificaram as estruturas urbanas de um modo sem precedentes, o que inclui, também, a relação cidade-campo (veja-se, por exemplo, o peso da fruticultura irrigada em Petrolina/PE-Juazeiro/BA e Mossoró/RN), a produção com novas plantas industriais, obedecendo muitas vezes a uma lógica externa, a reestruturação comercial e a ampliação das desigualdades socioespaciais com os processos de segregação e fragmentação socioespacial e a difusão de novos espaços de pobreza.

Dentre os resultados do processo de modernização capitalista, que alcançou o próprio espaço periférico do modo de produção capitalista, no caso do Brasil, está a precarização do trabalho que se dá pari passu com inserção de novos produtos tecnológicos e inovações que nos remete à tese de Oliveira (2003) da relação do novo e do velho como especificidade do capitalismo nacional e constitutiva do Ornitorrinco. A vida urbana e o trabalho estão conectados como nunca, como atestam Oliveira (2003), Maricato (2015) e Telles (2006), os quais apontam resultados desastrosos do processo de flexibilização no contexto das relações sociais, produtivas e da experiência urbana ou fundamentalmente, como as cidades contemporâneas se apresentam como lócus das relações trabalhistas exploratórias (FERRARI, 2005). 
Portanto, diante deste contexto até aqui discutido, será analisado como a reestruturação produtiva e a precarização do trabalho são fundamentalmente perversas e tem suplantado conquistas e direitos dos trabalhadores, e, em seguida, como tais transformações estão redefinindo o espaço urbano de Mossoró, levantando alguns questionamentos e hipóteses para a continuação da pesquisa.

\title{
TRANSFORMAÇÕES NO MUNDO DO TRABALHO E REESTRUTURAÇÃO PRODUTIVA NA PERIFERIA DO CAPITALISMO
}

A reorganização do mundo do trabalho é fruto da reestruturação produtiva do capitalismo, impulsionada pela mundialização do capital e por sua penetração nos mais diversos lugares. $O$ capitalismo redefine fronteiras geográficas, nacionalidades, culturas, civilizações, instrumentos administrativos e de gestão, legislações e sistemas de proteção aos trabalhadores. A análise de Marx e Engels (1999) no Manifesto Comunista continua extremamente atual:

\begin{abstract}
A burguesia não pode existir sem revolucionar constantemente os instrumentos de produção e, portanto, as relações de produção, isto é, todo o conjunto das relações sociais. Esta mudança contínua da produção, esta transformação ininterrupta de todo o sistema social, esta agitação, esta perpétua insegurança distinguem a época burguesa das precedentes. Todas as relações sociais tradicionais e estabelecidas, com seu cortejo de noções e idéias antigas e veneráveis, dissolvem-se; e todas as que as substituem envelhecem antes mesmo de poder ossificar-se. Tudo o que está estratificado e em vigor volatiliza-se, todo o sagrado é profanado, e os homens são finalmente obrigados a encarar a sua situação de vida, os seus relacionamentos mútuos com olhos sóbrios (MARX; ENGELS, 1999, p. 10 e 11).
\end{abstract}

A mundialização da economia, através do processo de globalização e a passagem para o período pós-fordista, alteraram significativamente as relações de trabalho no espaço e, neste quesito, Harvey (2006; 2016) trouxe excelentes contribuições. A flexibilização dos meios de produção, a dinâmica de uma reprodução ampliada e o sistema financeirizado da economia global conduzem ao surgimento do abominável mundo do trabalho precário4 (ALVES, 2007). Neste sentido, as condições postas pelo capitalismo na atualidade não conduzem necessariamente o trabalhador, que vende a sua força de trabalho, em assalariado sui generis ou como fora historicamente conceituado (proletariado), isto é, com as mesmas características dos trabalhadores dos séculos XIX e XX, por exemplo. O capitalismo recria permanentemente seus mecanismos de exploração e extração da mais-valor, ao passo que a luta dos contrários nunca foi tão intensa, ou seja, a luta entre os que detêm os meios de produção e os que não possuem e precisam vender sua força de trabalho ${ }^{5}$.

Antunes (2000), Souza (2012), Standing (2015) e Alves (2007) analisam que os empregos estáveis, ditos formais, dão lugar a uma massa de trabalhadores denominados autônomos ou que trabalham por conta própria; para alguns, esses são supostamente "livres" do mecanismo de exploração do novo mundo do trabalho, entretanto, não deixam de serem elementos compositivos do modo de controle sócio-metabólico do capital (MÉSZÁROS, 2011). São os chamados "faz tudo" que se propõem a realizar os mais diversos serviços, em troca de valores bem abaixo do que se cobra no mercado por empresas especializadas; são ainda camelôs ou trabalhadores que vendem novos serviços, na qual Alves (2007) denominou de proletários-mascates, enfim, são variados casos que poderiam ilustrar a precarização do mundo do trabalho contemporâneo.

\footnotetext{
${ }^{4}$ O próprio autor estabelece diferenciações entre precarização e precariedade. Para ele, a precarização é um processo histórico-social de perda de vínculos sociais com a produção do capital. É um deslocamento no espaço-tempo da condição de proletariedade. Ora, a superpopulação relativa em si, como categoria social, é expressão da precariedade do trabalho assalariado. Precariedade é uma condição histórico-ontológica de instabilidade e insegurança de vida e de trabalho. Mesmo o trabalhador assalariado que flui por conta dos ciclos industriais, explicita sua precariedade viva (a precariedade é uma dimensão ontológica do trabalho assalariado). Entretanto, o incremento da produtividade do trabalho tende a impulsionar o movimento de precarização do trabalho assalariado, explicitando, portanto, novas determinações da precariedade viva (ALVES, p. 102-103, 2007).

${ }^{5}$ Ver as definições de Standing (2015) sobre o precariado: "exército de desempregados e um grupo separado de pessoas hostis socialmente desajustadas, vivendo à custa da escória da sociedade (STANDING, 2015, p. 25)". Outras características que o autor associa a esta classe é a insegurança do vínculo empregatício, a renda precária e vulnerável, a heterogeneidade na composição e a raiva diante da frustração da vida cotidiana. Para descrever o contexto eminentemente europeu, o autor sinaliza que o precariado vive sobre uma fronteira, isto é, exposto entre as ações reacionárias propagadas por políticos populistas (movimentos anti-imigração, por exemplo) e ações progressistas e democráticas (luta pelos direitos sociais e trabalhistas).
}

$\begin{array}{lllll}\text { Caminhos de Geografia } \quad \text { Uberlândia-MG } & \text { v. 22, n. } 80 \quad \text { abr./2021 } & \text { p. 34-52 } & \text { Página } 39\end{array}$


O trabalhador assalariado e formal não foge desta precariedade, afinal, mesmo sob um regime que Ihe concede os direitos mínimos, no que se a legislação vigente, é perceptível que as condições do trabalho são demasiadamente extenuantes: longas jornadas de trabalho e o estabelecimento de "bancos de horas" para a concessão de folgas, método de trabalho repetitivo que inviabiliza a criatividade e a produção do conhecimento, frágeis direitos trabalhistas e organizações sindicais pouco atuantes, uso de métodos corporativos de fiscalização e vigilância para a extração de maisvalor absoluto, causando a deterioração física do trabalhador, aumento progressivo do deslocamento entre a área de trabalho e a residência, diminuindo o tempo de descanso, lazer e estudo e, a introdução de novos métodos de produção.

Desta forma, o trabalho morto sob a forma de máquinas assume o papel do trabalho vivo, desencadeando ainda, a redução do valor dos bens individuais produzidos. Logo, a classe trabalhadora torna-se cada vez mais flexível, fragmentada, complexa, difusa, fluída e fugaz, num processo permanente de redução do emprego regular em favor do trabalho em tempo parcial, temporário ou subcontratado (HARVEY, 2006).

Neste contexto, é possível colocar em evidência a permanência da contradição capital-trabalho, pois o fetichismo da mercadoria tem a capacidade de transformar a relação social entre seres humanos em uma relação entre coisas ou simplesmente a ocultação do trabalho social intrínseco. Para Alves (2007), esta característica, no imaginário social, fez com que a categoria trabalho, perdesse sua centralidade sociológica. Porém, a práxis transformadora que é exercida pelo trabalho ${ }^{6}$ funda a sociabilidade e a consciência do ser humano. Mesmo o trabalho vivo sendo substituído pelo trabalho morto, a necessidade do trabalho permanece e, portanto, a centralidade do trabalho continua efetivamente clara, embora de uma maneira completamente diferente quando se compara a épocas anteriores, ou seja, a ampliação dos serviços e do trabalho informal, em detrimento ao trabalho formal, expressa e valida a análise centrada na totalidade da vida social, sob a perspectiva histórica e dialética (ARAÚJO, 2009).

Todavia, as condições atuais promovidas pelo capitalismo subvertem esta ordem, o sujeito social não é visto como produtor social ou trabalhador, mas como consumidor de mercadorias. Com isso, as mercadorias serão produzidas não para satisfazer as necessidades da população, mas para a obtenção de lucros permanentes mediante a produção de novos desejos e necessidades. De modo que o ser humano não será visto a partir de suas habilidades cognitivas e suas especificações, mas simplesmente como coisas, obtendo-se a ideia do desenvolvimento da coisificação das relações sociais, atribuídas ao processo de produção (RUBIN, 1980). A novidade, aqui, é que isso é pautado na ampliação da circulação e sua concomitante redução do tempo de rotação do capital no espaço, algo que é intrínseco ao desenvolvimento e expansão histórico-geográfica do capitalismo por sucessivas rodadas de "compressões espaçotemporais" (HARVEY, 2006).

Logo, a morfologia dos trabalhadores de hoje, complexa, difusa e flexível, não é a morfologia social dos proletários do século XVIII, XIX ou XX e, com a expansão e reestruturação do capitalismo, a luta de classes que para alguns havia sido suprimida, tornou-se inversamente, mais intensa e exaustiva, assumindo assim, uma dimensão abstrata e recorrente (ALVES, 2007).

O que ocorre de fato é o aumento da exploração do trabalhador que acompanha as novas tendências da era pós-fordista, ou seja, um emergente modelo de acumulação flexível, cuja tendência atual é o aumento dos trabalhadores subassalariados ${ }^{7}$, que vivem à margem da produção material, com o

\footnotetext{
${ }^{6}$ No processo de socialização humana, o trabalho é encarado como o elemento que possibilitou a humanização dos sujeitos coletivos através do desenvolvimento das forças produtivas, ou seja, a capacidade de racionalização permitiu que o homem se distinguisse de outros animais e, consequentemente modificasse tanto a natureza como a ele mesmo, em suas dimensões objetivas e subjetivas. No modo de produção capitalista as relações sociais são dissolvidas e convertidas em relações mercantis, desta maneira o trabalhador é transformado em mercadoria e sua força de trabalho adquire um valor que, para garantir sua sobrevivência precisa vender à burguesia que detém os meios de produção (MARX, 2001). Na contemporaneidade, há uma reorganização do sistema produtivo promovendo algumas alterações no mundo do trabalho: redução do proletariado estável, ampliação do trabalho "intelectualizado" no interior das plantas produtivas e modernas, generalização do trabalho precário, o trabalho part-time e terceirizado na era da empresa "flexível". Portanto, a centralidade do trabalho no capitalismo atual continua presente, porém, com dimensões efetivamente diferentes (ANTUNES, 2000).

7 A Reforma trabalhista brasileira, aprovada em 2017, é o reflexo contundente da precarização dos direitos trabalhistas historicamente conquistadas. Foram mais de 100 artigos alterados na CLT (Consolidação das Leis Trabalhistas) e a criação de duas modalidades de contratação: trabalho intermitente (por jornada ou hora de serviço) e a do teletrabalho, chamado de home office (trabalho a distância). Entre as mudanças estão:
}

$\begin{array}{lllll}\text { Caminhos de Geografia } \quad \text { Uberlândia-MG } & \text { v. 22, n. } 80 & \text { abr./2021 } & \text { p. 34-52 } & \text { Página } 40\end{array}$


aumento da informalidade, dos flexíveis, dos trabalhadores precarizados, do desemprego estrutural, dos temporários, com forte teor de precariedade socioespacial e da diminuição do poder sindical (VASAPOLLO, 2007). Há, portanto, um aumento gradual da classe dos precariados ${ }^{8}$ :

Para compreender por que o precariado está crescendo, deve-se avaliar a natureza da Transformação Global. A era da Globalização (1975-2008) foi um período em que a economia se "desintegrou" da sociedade na medida em que financistas economistas neoliberais buscaram criar uma economia de mercado global baseada na competitividade e no individualismo (STANDING, 2015, p. 49).

O capitalismo flexível tornou o espaço geográfico cada dia mais complexo em seus aspectos econômicos, políticos, sociais e culturais, tendo, as próprias relações socioespaciais também sofrido alterações substanciais (HARVEY, 2006). Não é diferente, portanto, no campo do trabalho, com o crescimento de precarizados e subempregados, o aumento do desemprego estrutural (e não apenas conjuntural), a volatilidade da mão-de-obra, a fragmentação da classe trabalhadora ou ainda a flexibilização (amparadas pelo Estado) de leis e direitos historicamente conquistados pela classe trabalhadora brasileira ao longo de décadas, por exemplo. Isso tudo vem se agravando com o uso de plataformas digitais e do discurso ideológico do empreendedorismo (DARDOT; LAVAL, 2016).

O capitalismo, portanto, tem a capacidade de alterar fronteiras geográficas (MARX; ENGELS, 1999) e consolidar a inserção de fixos que dinamizam os fluxos, a ciência e a tecnologia (SANTOS, 1996) para uma parcela da população em detrimento da maioria (SANTOS, 2003). É nesse processo emblemático que a cidade de Mossoró, como outras cidades brasileiras, se insere no contexto supracitado e que, a partir de agora, buscar-se-á analisar num esforço de compreensão dos nexos existentes entre a precarização do trabalho nas periferias do capitalismo a partir das cidades médias como espaços de acumulação e reprodução do capitalismo. As lógicas mais gerais e abstratas do modo de produção vigente, que redefinem as formas de trabalho, consumo e, portanto, de produção da cidade e do urbano, se evidenciam na cidade de Mossoró, tanto nas formas urbanas e na paisagem, como nos conteúdos que vem assumindo mediante os conteúdos que o trabalho vem assumindo no Brasil e no mundo na atualidade.

\section{DESEMPREGO, PRECARIZAÇÃO NO CONTEXTO DAS CIDADES MÉDIAS: APONTAMENTOS DE UMA PESQUISA EM CURSO EM MOSSORÓ}

As mudanças na produção e no consumo, bem como na própria circulação do capital em escala global, reverberaram em Mossoró de uma maneira bastante significativa. A cidade tem sua localização no oeste do estado do Rio Grande do Norte e, de acordo com o censo de 2010 do Instituto Brasileiro de Geografia e Estatística (IBGE), sua população era estimada em 259.815 mil habitantes. Em 2019, a população estimada eleva-se para 297.378 habitantes (IBGE/CIDADES, 2020).

Historicamente, a dinâmica econômico-territorial do município e sua expansão remetem-se à extração de recursos naturais e produção de pecuária intensiva no século XVIII, beneficiada pela localização geográfica de transição entre sertão e litoral (ROCHA, 2005; ELIAS e PEQUENO, 2010). Já ao final do século XIX e início século XX as atividades salineiras e de oleaginosas, como o algodão e a

convenções e acordos coletivos que poderão prevalecer sobre a legislação, jornada de até 12 horas com 36 horas de descanso e o pagamento do piso ou salário mínimo deixa de ser obrigatório no cálculo da remuneração por produtividade. Além disso, trabalhadores e empresas poderão negociar todas as formas de remuneração, que não precisarão fazer parte do salário. Enfim, criaram-se uma série de mecanismos que estimularam, essencialmente, o trabalho precário e informal, comprometendo inclusive o consumo das famílias brasileiras (LIMA, 2018). Ao final de 2019, já sob o governo Bolsonaro, o Senado aprovou em segundo turno a proposta de emenda à Constituição (PEC) que reformou a previdência na alíquota progressiva, nas regras de transição, Benefício de Prestação continuada (BPC), aposentadorias especiais, etc. (MÁXIMO, 2019). Paralelamente, houve aumento gradativo do trabalho informal nos últimos anos (AMORIM, 2019) e, a decretação do fim do Ministério do trabalho em 2019. Esses eventos exemplificam a fragmentação dos direitos trabalhistas ao longo dos anos no Brasil.

${ }^{8}$ Mantém-se o termo precariado, da mesma maneira utilizada no texto do autor citado, todavia, utilizamos ao longo do texto, mais frequentemente, a terminologia precarizado.

$\begin{array}{lllll}\text { Caminhos de Geografia } \quad \text { Uberlândia-MG } & \text { v. 22, n. } 80 & \text { abr./2021 } & \text { p. 34-52 } & \text { Página } 41\end{array}$


carnaúba, consolidaram o crescimento populacional e a formação de um centro regional por conta da produção e comercialização, garantindo a instalação de indústrias e das agroindústrias para a intensificação do desenvolvimento agrícola e, de uma elite no local ${ }^{9}$, fortalecendo o papel da cidade como centro distribuidor e sede industrial (ROCHA, 2005).

Nas décadas de 1940 e 1950 há um processo de intensificação rodoviária que desencadeia a expansão urbana em direção à noroeste e sudoeste, possibilitando a ocupação da margem direita do rio Mossoró, o principal que corta a cidade. A forte influência do Estado (nas mais diversas esferas) através de investimentos e direcionamento de expansão, institucionalizada inclusive pelo Plano Diretor da cidade (1975), permitiu a consolidação de uma zona universitária a sudeste, implementação do distrito industrial e habitação socia de interesse socia a noroeste (ROCHA, 2005; ELIAS e PEQUENO, 2010).

Já entre as décadas de 1980 e 1990, há o impulsionamento de novas atividades econômicas, através do petróleo ${ }^{10} \mathrm{com}$ a Petrobrás e da fruticultura irrigada, destacando-se o polo fruticultor Açu-Mossoró, com a produção de melão, abacaxi, melancia, castanha de caju e mamão. Todavia, é uma atividade altamente concentradora de terras, que cresceu na esteirados investimentos estatais da Superintendência de Desenvolvimento do Nordeste (SUDENE) e do Polo de Desenvolvimento Integrado Açu-Mossoró. Destaca-se também, a extração do sal ${ }^{11}$. Estas atividades terminaram por dinamizar outros setores da economia local, como o setor imobiliário, o comércio, serviços e lazer, com potencial ascensão em anos posteriores (SOARES, 2015).

Todavia, a crise econômica no país, que desde 2015 vem se agravando, resultou em uma desaceleração em setores produtivos (por exemplo, no ramo da construção civil). Nesse ínterim, ampliou-se o desemprego e o trabalho informal, amparadas por reformas de cunho neoliberal e pelo discurso da flexibilização e do "empreendedorismo". O impacto do trabalho no contexto urbano, por exemplo, é notório e evidencia-se pelo aumento da informalidade, na entrega de alimentos ou no transporte de passageiros, a partir de aplicativos ou mesmo no desempenho de trabalhos temporários, degradantes e insalubres.

Para exemplificar, a partir do contexto brasileiro incialmente, no trimestre encerrado em setembro de 2019, dados do IBGE revelaram um aumento no número de pessoas ocupadas no país. Todavia, o contingente de indivíduos que conseguiu trabalho no período está em condição de informalidade, atingindo um recorde da série histórica que alcançou $41,4 \%$ da força de trabalho ocupada. Neste grupo estão os trabalhadores sem carteira assinada (setor privado e domésticos), os sem Cadastro Nacional da Pessoa Jurídica (empregadores e por conta própria) e os sem remuneração (auxiliam em trabalhos para a família). A categoria por conta própria foi outro segmento que cresceu neste período, apresentando outro recorde com 24,4 milhões de pessoas nesta condição, repercutindo na estagnação do ganho médio habitual e diminuição contínua da população que contribui com a previdência (NITAHARA, 2019).

No contexto regional e local, paralelamente, há um quadro progressivo de redução do emprego formal (Figura 1), especialmente a partir de 2010 e o número de trabalhadores informais, como no estado do Rio Grande do Norte, tem registrado um elevado crescimento, com cerca de $15,8 \%$ no primeiro trimestre de 2019, em comparação ao primeiro trimestre de 2018, ou seja, cerca de 372 mil trabalhadores atuavam na informalidade neste período (ARAÚJO, 2019).

\footnotetext{
${ }^{9}$ Paralelamente, esta expansão é consolidada e amparada pelo acesso à terra cada vez mais restritivo no país, com a Lei de Morgadio de 1835 que institucionalizava a sucessão de terras e a manutenção do latifúndio e, a Lei de Terras de 1850, cujas terras devolutas passavam a ser do Estado e, sua apropriação, dava-se apenas através da compra e venda, estimulando desta forma, a tradição latifundiária brasileira (CAVALCANTE, 2005).

10 A exploração de petróleo (1980-1990) pela Petrobras, notadamente conhecida com uma das mais importantes explorações por terra do país, impulsionou a instalação de uma série de empresas que dão suporte à atividade: perfuração de poços, fornecimento de mão de obra, manutenção industrial e locação de equipamentos, mão de obra especializada em petróleo e gás, serviços de manutenção, instalação, montagem e operação de equipamentos (DOMINGUES, 2014).

11 O Rio Grande do Norte produz aproximadamente de $90 \%$ da produção brasileira, com forte participação de Mossoró. Na produção e comercialização destacam-se as de capital estrangeiro (BEZERRA et al., 2012).
} 
Figura 1 - Saldo de empregos formais na cidade de Mossoró-RN, série histórica.

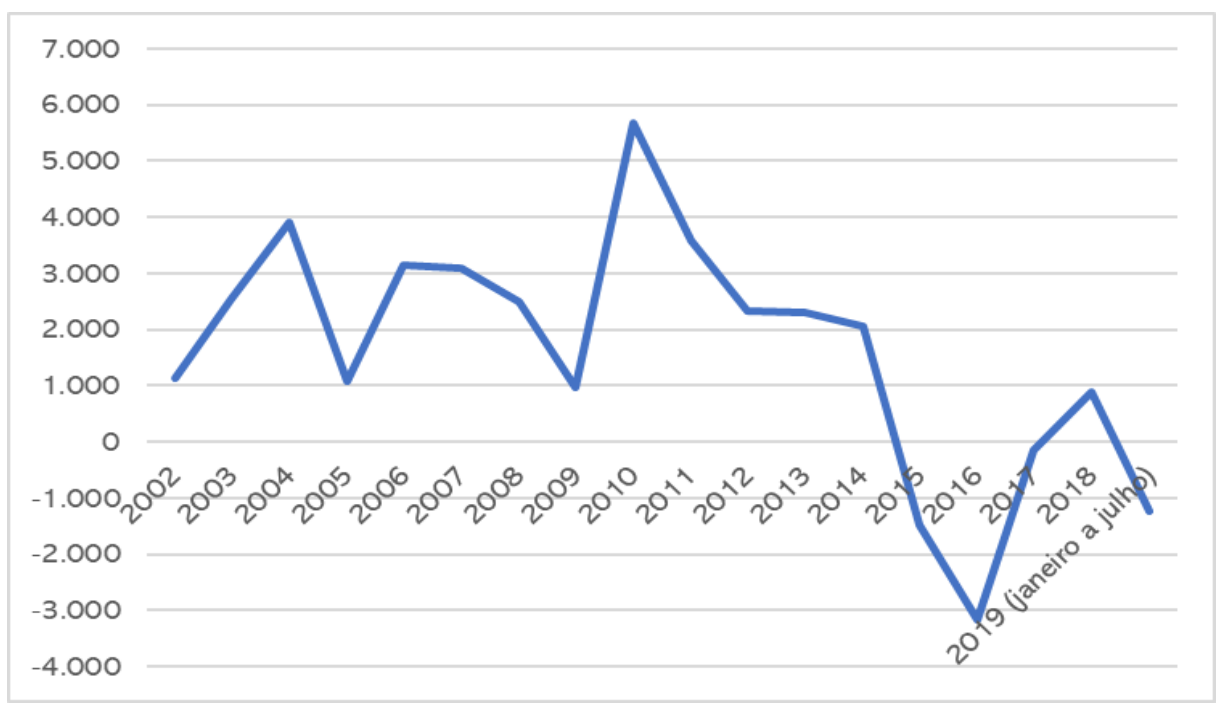

Fonte - BRASIL (2019).

A cidade de Mossoró, com uma economia importante (conforme já frisado), através da forte diversificação das atividades econômicas como a extração do petróleo, agricultura irrigada e produção do sal, além do comércio, serviços e instalação de indústrias, vem sendo influenciada pela forte crise econômica nacional nos últimos anos, a privatização e o desinvestimento em setores produtivos como a Petrobrás, além da desaceleração econômica, impactando, portanto, a economia urbana, com a redução de empregos formais, em setores importantes da economia local. Percebe-se, por exemplo que mesmo com uma recuperação e um pequeno crescimento, a partir de 2009, na agricultura, pecuária, produção florestal, pesca e aquicultura (insere-se neste setor a agricultura irrigada), houve redução do saldo de empregos nos outros setores analisados, especialmente no ramo da construção civil, a partir do ano de 2011 (Figura 1).

Se analisarmos o saldo de empregos formais ao longo dos anos na cidade Mossoró de maneira mais ampla, ou seja, englobando várias outras atividades (lazer, comércio, serviços, indústria, etc.), percebe-se uma redução significativa, num quadro que se assemelha à própria conjuntura nacional, ou seja, o crescimento de setores informais, precários e o encolhimento dos empregos formais nos mais diversos setores da economia urbana (Figura 2).

Figura 2 - Saldo de empregos por setor de atividade econômica em Mossoró-RN, 2019.

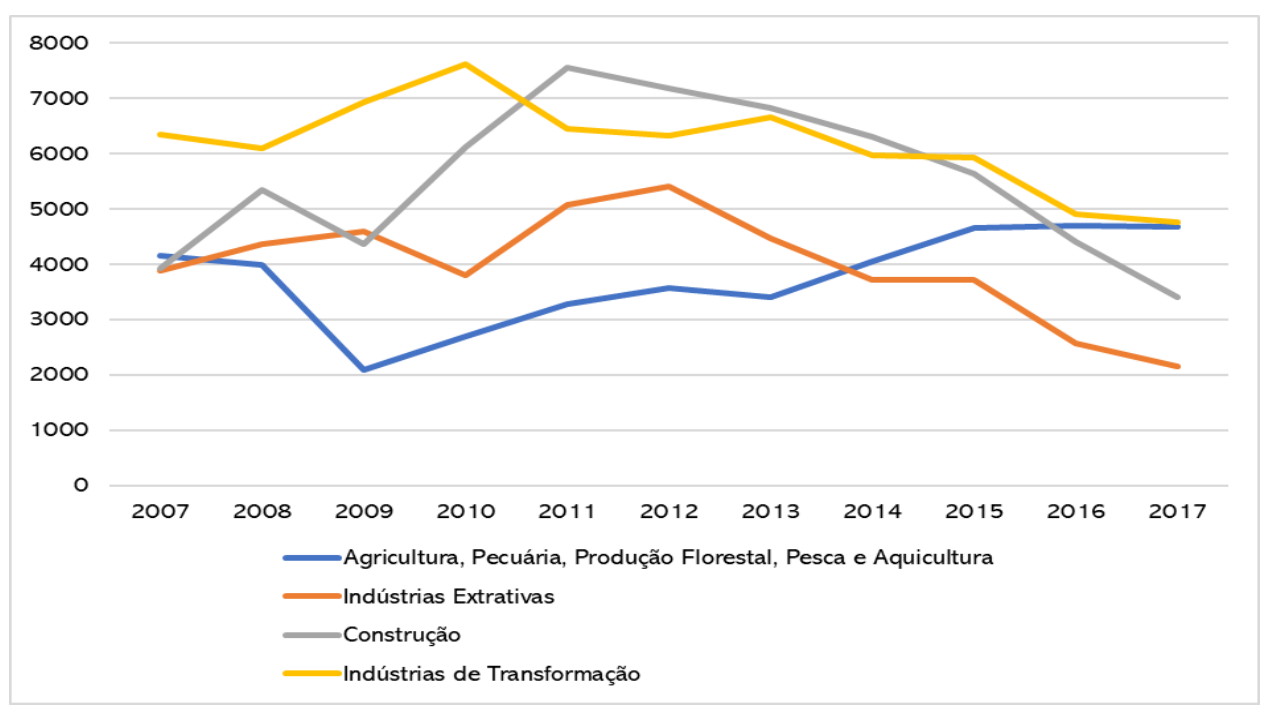

Fonte - BRASIL 2019). 
O que se pode ver é a caracterização de dois momentos importantes que tem relações com a própria dinâmica econômica da formação socioespacial. Por um lado, momento de crescimento econômico baseado em alguns pilares que foram importantes para a economia nacional (investimento em infraestrutura, consumo, políticas públicas de combate à pobreza, políticas sociais de aumento real do salário mínimo) e que pode se situar aproximadamente de 2004 até mais ou menos o ano de 2014 (SINGER, 2012; POCHMANN, 2014); por outro lado, de 2014 até o presente momento, a prevalência de um período de crise e de radicalização político-econômica da agenda neoliberal após o impeachment de 2016 (SILVA, 2016; SINGER, 2016).

A radicalização desta agenda ampliou os problemas advindos da crise, como o desemprego, a miséria e a pobreza, ao passo que o capital viu, aí, uma oportunidade para que novas lógicas pudessem ser postas em prática. O neoliberalismo, em sua dinâmica que não pode se resumir somente à "macroeconomia" como normalmente é associado, produziu um "novo sujeito", "empresário de si mesmo" (DARDOT; LAVAL, 2016) em escalas espaciais diversas, do local ao global. Novas formas de trabalho, já presentes em países do capitalismo avançado, entraram em voga com toda a força no Brasil com ampla divulgação diária nas mídias e redes sociais, principalmente por meio da televisão. A ideologia do empreendedorismo que não é mais que a precarização do trabalho contemporâneo, agora constitui parte da vida cotidiana em diversas cidades, incluindo as cidades médias. É importante mencionar que diversos estudos vêm mostrando ao longo dos últimos quatro anos que a mobilidade social conseguida desde o início da década de 2000 vem se alterando, e na verdade se invertendo.

O quadro de pobreza, miséria e desigualdades da formação socioespacial brasileira no período contemporâneo vem sendo demonstrado em um conjunto de estudos, por exemplo Oxfam Brasil (2017, Neri (2019) e IBGE (2020). Tal conjuntura contradiz, por exemplo, o argumento segundo o qual uma maior radicalização pró-mercado irá aumentar e ampliar os empregos formais, o que de certo modo parece ter sustentação nos dados divulgados no início do presente ano (em 2020), em que o número de empregos com carteira assinada superou as expectativas do governo brasileiro em 2019, sendo o melhor resultado desde 2013. Isso sugere, segundo o argumento dominante, que quanto maior for a flexibilização do trabalho e mais ampla for a extensão do domínio das liberdades de mercado, melhor será para a estrutura do emprego. Todavia, o que esses números escondem é que o grau de concentração de renda tem se ampliado, o número de trabalhadores em empregos precários e informais tem subido, alcançando números recordes, e as desigualdades e a pobreza cresceram significativamente nos últimos anos (ANTUNES, 2018; POCHMANN, 2018).

A conjuntura de desemprego fez crescer substancialmente os subempregos, caracterizados pelo uso de plataformas digitais. Exemplo comumente conhecido é o Uber, cujo impacto, segundo Fontes (2017), já gerou termos como "uberização das relações de trabalho" e um verbo, uberizar; todavia, o Uber não é o único a lançar-se no mercado como expressão de "tecnologia", produtora de bens "imateriais", isto é, tenta passar a ideia de ser apenas uma plataforma, que reúne consumidores e ofertantes de serviços, isentando-se da total responsabilização de vínculos trabalhistas. Na verdade, há um controle efetivo do trabalhador, a desobrigação de impostos, de taxas, da manutenção do transporte e uma centralização do comando sobre os trabalhadores (FONTES, 2017). Algumas empresas que operam no Brasil, através dos serviços de entrega e transporte por meio de plataformas digitais como Uber, UberEats, iFood, Loggi, Rappi e Bee (esta última empresa em particular será analisada mais adiante), assumem o discurso do empreendedorismo, do trabalhador ser administrador do seu tempo, ser autônomo e não estar submetido ao "patrão" entre outros termos.

Entretanto, trabalhos recentes, tem demonstrado a precarização do trabalhador e a condição degradante de suas funções, como atestam Slee (2017), Fontes (2017), Abílio (2017), Sabino e Abílio (2019) quando apontam algumas características do trabalho através das plataformas digitais, como a atividade dos trabalhadores não estarem associadas à inovação; rastreamento arbitrário dos movimentos do entregador/motorista; não se enquadrarem como detentores de capital; não possuírem ingerência na tomada de decisões dos negócios; estarem submetidos a uma nova forma de gerenciamento, controle e de atendimento ao consumidor; sistema de avaliação que vai se constituindo como gerente coletivo, pelos consumidores e risco de desligamento ao não aceitarem determinadas tarefas, no envolvimento em má conduta e em manifestações políticas contra a empresa.

Tal ênfase é importante pelo fato de Mossoró ser um subespaço dinâmico (SANTOS, 1996, p. 165) de destaque no conjunto das cidades médias nordestinas e ter uma centralidade no âmbito da atuação e funcionamento destas lógicas. Com isso, queremos dizer que a lógica da precarização por 
meio da "uberização" e da "plataformização"12 não é apenas reproduzida em Mossoró; essa lógica é, de fato, produzida na cidade por meio da empresa de capital local de entregas Bee. Em outras palavras, além de Mossoró apresentar empresas que são de capitais externos ao lugar funcionando na cidade, como a Uber, 99Táxi, iFood, isto é, que reproduzem a lógica do capitalismo e da precarização contemporânea, encontramos também, nesta cidade, empresas de capital local que tem buscado inserir-se no mercado, como a Bee Delivery, que tem repercutido esta lógica para todas as regiões brasileiras e com pretensões de internacionalização (CARVALHO, 2019). A (re)produção ativa da lógica do capitalismo globalizado em Mossoró se dá, assim, em conjunção com as transformações globais da totalidade social e mundial, que alinhou o trabalho com a flexibilização e a precarização juntamente com a produção do novo sujeito no capitalismo financeiro e neoliberal.

A inserção da Empresa Bee e suas ramificações num contexto de flexibilização e precarização das relações de trabalho e de ascensão de aplicativos é algo que precisa ser destacado e discutido. Fundada em $2018^{13}$, a empresa de entrega Bee Delivery é um reflexo do atual momento do capitalismo. A iniciativa de fundar uma empresa de entrega de mercadorias veio a se materializar quando as transformações tecnológicas engendradas pelo capitalismo se combinaram com uma reestruturação e precarização do trabalho. As transformações mais amplas em termos de funcionamento do modo de produção pavimentaram o terreno para que iniciativas particulares desta natureza pudessem se concretizar.

A estrutura do emprego transformada - inclusive em relação à regulação e ao papel do Estado deixou um campo aberto para que startups passassem a ocupar um espaço deixado pelo drama da miséria e do desemprego no que se refere às ocupações. Esse novo espaço geográfico produzido sob a globalização, que Santos (1996) qualificou como "meio técnico-científico-informacional" constitui a condição necessária para o florescimento destes agentes econômicos, tanto no que se refere aos de ação internacional, quando os locais que tentam entrar no mercado e competir para buscar a ascensão. Existem, ainda, projetos que visam o uso de drones e robôs nas entregas, como relatam representantes do iFood (MOURA, 2020, o que poderá aprofundará a precariedade das relações de trabalho e a pobreza, e exigirá mais esforços de análise.

A empresa Bee tem um diferencial que é interessante de se observar. Ela surge de uma cidade que, no que se refere à estrutura da rede e do sistema urbano nacional, não tem uma expressão tão significativa como as metrópoles. Com isso queremos dizer que é no estrato da rede urbana ocupado pelas cidades médias que um novo agente econômico surge e explora, de maneira crescente, o espaço nacional. Essa exploração do espaço é entendida como o uso do território (SANTOS, 1996), ampliando suas ações de forma expansiva em vários estados do Brasil e nas principais cidades do país, incluindo os espaços metropolitanos.

As grandes empresas do mesmo ramo, como iFood, Uber Eats, tem estratégias espaciais distintas: a primeira atua em mais de 500 cidades do Brasil, incluindo cidades pequenas e médias; a Uber Eats atua preferencialmente em espaços metropolitanos, e outras muitas empresas estão buscando concorrer nos locais onde surgem, já de olho na importância das cidades médias como mercado de consumo e de novas formas de trabalho (MOURA, 2020). Ou seja, há uma certa capilaridade que permite entender como a atuação desse agente econômico, de certo modo, reposiciona a cidade de Mossoró no contexto da organização socioeconômica e urbana do Brasil, tornando-a um novo nó da rede de cidades no que se refere às novas tecnologias de informação, onde se encontram, como mencionado anteriormente, outras empresas do mesmo ramo em funcionamento.

Como parte dos primeiros trabalhos de campo realizados para a pesquisa já citada no início deste artigo, observamos por meio de entrevista e de observações in loco que a empresa Bee tem, ainda, pouco tempo de funcionamento e vem obtendo um crescimento rápido e substancial, saltando escalas geográficas (SMITH, 2000), reproduzindo uma nova forma de trabalho e de relações de trabalho em Mossoró e em outros estados do Brasil. A empresa está presente em 24 estados do

12 Sobre o tema capitalismo de plataforma, consultar o trabalho de Bruna Della Torre (2019) sinalizado nas referências.

${ }^{13}$ Os fundadores são Thales Patreze, com os sócios Luan Rodrigues e André Ramon (CARVALHO, 2019). De acordo com o site Consultasocio.com, que busca informações cadastrais e quadro societário dos idealizadores, "Thales Patreze De Souza Soares" é sócio em cinco empresas, sendo três em Mossoró, uma em Natal (ambas no RN) e uma no estado de São Paulo, todas no ramo de tecnologia, com capital social de 320 mil reais. "Luan Rodrigues" possui participação nas mesmas empresas com capital social de 300 mil reais e "André Ramon" é sócio em três destas empresas no RN e uma em SP, com capital social de 240 mil reais (CONSULTASOCIO, 2020). 
Brasil e com mais de 70 franquias ${ }^{14}$ e em 81 cidades, conforme consta em seu sítio eletrônico (BEE DELIVERY, 2019). Sendo Fortaleza, Manaus, Natal, Barreiras e Teresina algumas das cidades que tem as maiores operações (ver figura 3). As redes sociais como Facebook e Instagram foram essenciais para essa expansão geográfica da empresa para todos as regiões do Brasil ${ }^{15}$.

A flexibilidade é, para a empresa, quase que "logomarca" ou "lema", como pode ser lido em seu site: "Flexível como você: nossos entregadores podem escolher entre bike, moto, carro, picape ou van". Isso faz da empresa uma entregadora de qualquer tipo de mercadoria, e não apenas de alimentação, funcionando em parcerias com outras empresas, com o iFood (CARVALHO, 2019; BEE DELIVERY, 2019), por exemplo ${ }^{16}$, e, tenha iniciado suas atividades mediante a "transformação de pessoas em motoboys $^{17}$ ", serviço que não existia na cidade antes da criação da empresa, ao passo que as entregas eram realizadas por mototaxistas.

Figura 3 - Brasil. Distribuição espacial das operações da Bee Delivery no território nacional, 2020.

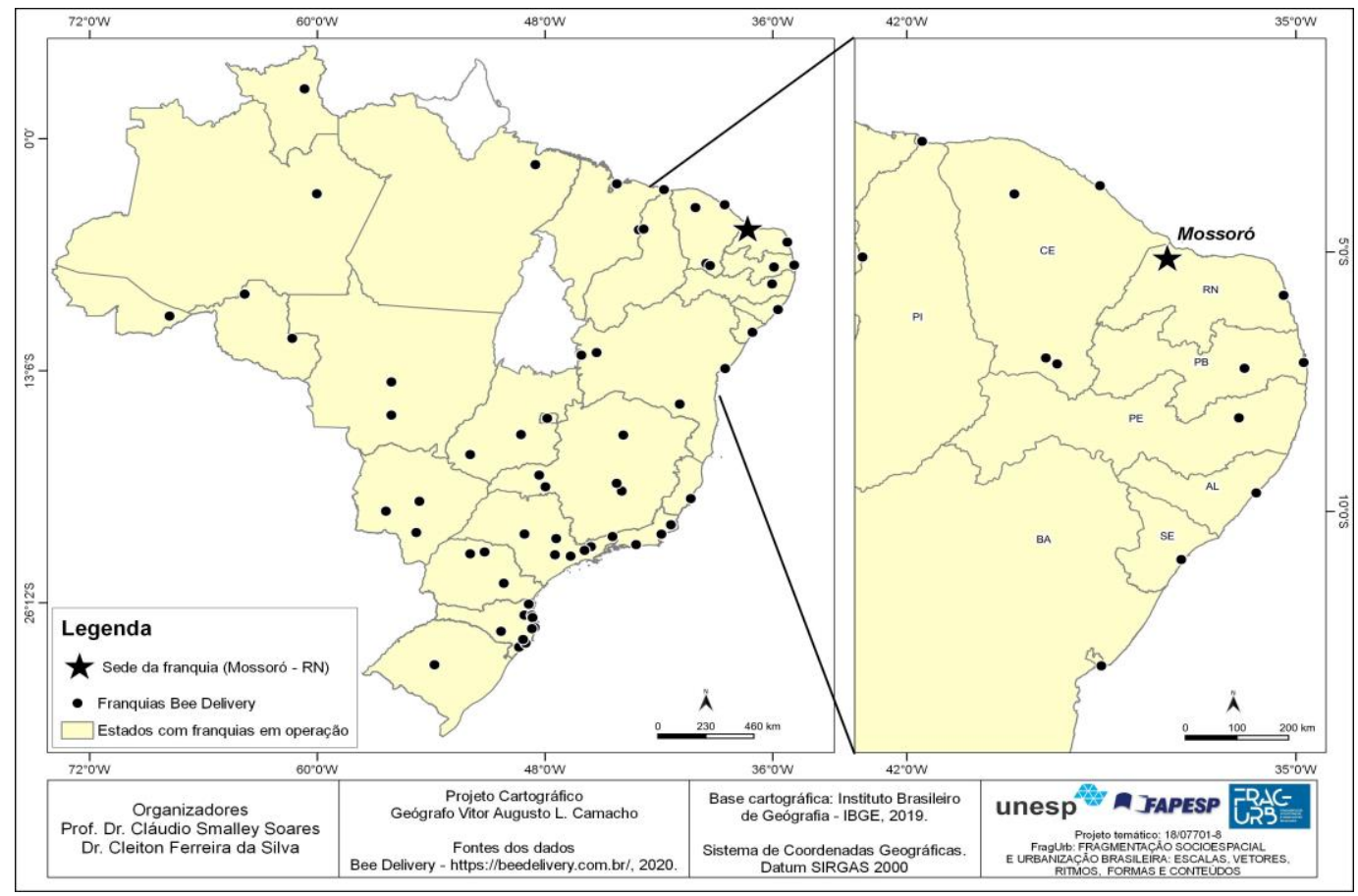

Fonte - Bee Delivery (2020); Base Cartográfica: IBGE, (2019).

O tipo de serviço é semelhante ao Uber, ou seja, o entregador fica à espera de ser chamado para uma entrega, tal qual os motoristas do aplicativo Uber, que são chamados para transportar alguém. São, em média, 300 entregadores ativos na cidade de Mossoró no decorrer de um mês, e com aproximadamente 100 mil entregadores (motoboys e bikers) cadastrados (BEE DELIVERY, 2019) e 50 mil empresas em todo Brasil, tendo inclusive, ultrapassado o número de dois milhões de entregas em outubro de $2019^{18}$. A nomeação desse processo de "uberização", conforme discutido acima, parece estar de acordo com essa nova forma de trabalho precário que, aliás, tem alguma relação com o próprio nome da empresa, "Bee" de abelha em inglês, que ao ser explicada pelo CEO, Thales,

$14 \mathrm{O}$ franqueado adquire a tecnologia para empresas com um custo de aproximadamente $\mathrm{R} \$ 10$ mil, as quais passam a oferecê-la na cidade preterida. Além disso: "toda a logística de cadastro e captação de clientes é feito pelo franqueado, o que adquiriu o produto lá na ponta". Informação cedida por meio de entrevista realizada em outubro de 2019.

15 Informação cedida por meio de entrevista realizada em outubro de 2019.

${ }^{16}$ Informação cedida por meio de entrevista realizada em outubro de 2019.

17 Em análise sobre a distribuição da frota do Rio Grande do Norte no site do Detran, segundo o tipo de veículo em 09/04/2020, a cidade de Mossoró possuía a segunda maior frota de motocicletas do estado e a primeira em número de motonetas, são 53.284 e 16.960 respectivamente (DETRAN, 2020).

18 Informação cedida por meio de entrevista realizada em outubro de 2019. 
afirmou: "As abelhas por essência fazem 'deliverys' com a polinização das flores. Além disso, trabalham desde o primeiro até o último dia de vida" (CARVALHO, 2019. Grifo nosso).

A flexibilidade em sua dimensão do trabalho urbano se alia à tecnologia substituindo o contato face-aface entre empresa e funcionário. Esse é uma dimensão de esfacelamento da sociabilidade urbana que parece estar se ampliando, devido às transferências para as plataformas digitais e on-line dos serviços que antes eram realizados presencialmente. Foi exatamente isso que aconteceu com a Bee, que após conseguir um grande número de entregadores cadastrados, e ao operar em outros estados do Brasil, substituiu o atendimento presencial e face-a-face, o que incluía, também, treinamentos para os entregadores, para uma relação mediada somente pelo objeto técnico smartphone, que tem todas as informações necessárias para os cadastrados, inclusive vídeos de treinamentos, que são disponibilizados na mesma plataforma de cadastro e é um dos poucos pré-requisitos, para o início de operação das entregas pelo trabalhador. Soa, portanto, como uma desburocratização do tempo de giro do capital e a velocidade da reprodução econômica que, em verdade, se torna mais efetiva em virtude dos avanços tecnológicos.

Essa nova forma de trabalho, como já mencionado, se encaixa perfeitamente no atual contexto do capitalismo, e a precarização assume um papel central, pois contribui para a redefinição da vida urbana nas periferias do capitalismo. As mudanças no mundo do trabalho favoreceram o redesenho dos mundos sociais, que se traduziram em relações entre o mundo do trabalho e nas dinâmicas urbanas. As novas configurações sociais e urbanas mediante as mutações do trabalho e do capitalismo mostram um deslocamento dos dispositivos de emprego para as formas variadas de trabalho precário, intermitente e descontínuo, conforme destacou Telles (2006).

Nesse interim, a vida se processa a partir na redefinição dos espaços urbanos caminham lado a lado com novas tessituras sociais que dão novos sentidos e conteúdos aos espaços em que a vida se realiza, o que inclui os "circuitos de consumo" que atravessam desde os capitais globais até os mercados mais populares (TELLES, 2006).

Importa, para nós, compreendermos que a paisagem urbana, em sua forma mais simples, isto é, o seu aspecto tangencial, bem como o próprio espaço urbano estão sendo transformados de uma maneira inédita. As relações de trabalho que compõem essa nova dinâmica espacial e urbana apresenta novos conteúdos, relações e contradições. A paisagem urbana de Mossoró, nesse sentido, expressa uma estrutura social assimétrica resultante de um processo histórico-geográfico, e que vem aprofundando esta desigualdade por meio da agudização do capitalismo. Esse aprofundamento das desigualdades está para além dos fixos geográficos que compõem a morfologia urbana, embora por meio deles possam ser, também, analisados. As articulações entre escalas geográficas que se intensificam no capitalismo atual redefinem, assim, a escala urbana, sendo as relações de trabalho e a precarização da vida um aspecto que não pode ser deixado de lado.

As conexões que se estabelecem entre trabalho e cidade precisam ser mais bem analisadas, sobretudo se pensarmos em cidades médias. O trabalho é um importante conector do mundo social e do estabelecimento de referências para as práticas sociais e espaciais no urbano. A necessidade de compreender que no mundo do capitalismo flexível, em que saltam aos olhos os empregos precarizados, articulados à lógica de valorização do capital e da ideologia do empreendedorismo, nos remete ao fato de que "outra experiência de trabalho [significa, também] outra experiência urbana" (TELLES, 2006, p. 181) ao passo que a desregulamentação do mercado de trabalho, tem transformado as cidades latino-americanas em espaços desiguais e fragmentados, tal como conclui Mattos (2006 p. 50-51):

[...] as políticas de liberalização, desregulamentação e flexibilização, em conjunto com a terceirização da base econômica, promoveram processos de desestruturaçãoreestruturação dos regimes de trabalhos existentes, o que levou a um crescente decréscimo dos salários e precarização da força de trabalho e, com isso, em uma acentuação das desigualdades sociais, sob novas formas de exclusão, segregação, fragmentação e favela ${ }^{19}$, que têm afetado negativamente a vida social da maioria dos grandes aglomerados urbanos (Tradução nossa).

A reestruturação produtiva e a desregulamentação do trabalho têm tornado, portanto, cidades cada dia mais desiguais e excludentes, cujas relações estão estritamente ligadas a esta fase de modernização capitalista e aumento da sua rentabilidade mundializada.

19 O termo aqui empregado refere-se a espaços residenciais precários e com condições mínimas de habitabilidade nas cidades, seja na área da saúde, no serviço de transporte, na educação ou mesmo no cotidiano dos seus residentes. 


\section{CONSIDERAÇÕES FINAIS}

Este artigo constitui uma primeira investida a respeito das relações entre precarização do trabalho e produção do espaço urbano em cidades médias. Foi possível observar que estas relações precisam ser, atualmente, mais bem compreendidas, pois fazem parte de um contexto do capitalismo que está se transformando rapidamente, impactando a produção do espaço em variadas escalas. A precarização do trabalho com reformas que fragmentam os direitos trabalhistas e a ascensão da subcontratação e do trabalho meramente informal, por exemplo, são eventos que estão se tornando cada vez mais presentes com a radicalização neoliberal que se tornou a regra com o governo Temer e, agora, com o governo Bolsonaro. O fim do Ministério do Trabalho em 2019, por exemplo, diz muito sobre tudo isso.

A atenção foi dada primeiramente às transformações do capitalismo pós-fordista e seus impactos na vida social e na organização do trabalho. A precarização emergiu, como vimos, no contexto de aprofundamento das desigualdades socioespaciais e socioeconômicas, que afligem populações do mundo inteiro, com análise particular no Brasil. É nesse contexto que surgem as empresas de aplicativos que tem aproveitado a "destruição criativa" (para usar um termo que Harvey (2006) toma emprestado do economista Joseph Schumpeter) provocada pelo neoliberalismo para se imporem enquanto tendência.

Mas, como relatado no início do texto, foi uma primeira aproximação do problema, o que fez que pudesse ser optado por organizar e sistematizar as ideias a partir das informações disponíveis até então. Em termos práticos isso se refletiu nem uma suspensão momentânea a respeito da investigação sobre as relações de trabalho e a experiência urbana, aspectos que serão tratados no decorrer da pesquisa que baseia este artigo. Dito de outro modo, focamos aqui a maneira como a reestruturação do capitalismo na periferia do sistema tem impactado as cidades médias (no caso, Mossoró), e como uma empresa surgida nesta cidade tem aproveitado as condições existentes atualmente para pôr em prática uma lógica de funcionamento que vai ao encontro das dinâmicas encontradas em espaços metropolitanos brasileiros e vários lugares do mundo.

A maneira como os trabalhadores têm vivenciado esta nova dinâmica social, econômica e espacial é algo que investigaremos no curso da presente pesquisa. Assim, encerramos com o levantamento de alguns elementos e questionamentos que serão importantes ao longo da pesquisa que está sendo realizada, da qual este estudo faz parte. Quais os impactos destas tecnologias no trabalho contemporâneo? De que maneira estas empresas têm interferido na dinâmica socioespacial das cidades? Como tem se comportado a luta de classes no contexto da produção do espaço em tempos de "uberização" e "capitalismo de plataformas"? Esse novo mundo do trabalho apresenta especificidades nas cidades médias? Como a segregação e a fragmentação socioespacial expressam essas novas dinâmicas do mundo do trabalho no capitalismo pós-fordista? Quais as características socioespaciais dos trabalhadores de aplicativos em cidades médias? As três últimas perguntas constituem a parte mais relevante de nossos interesses imediatos, e ajudarão a problematizar as outras questões postas anteriormente.

\section{AGRADECIMENTOS}

Os autores agradecem à Fundação de Amparo à Pesquisa do Estado de São Paulo (FAPESP), no financiamento do Projeto Temático: "Fragmentação socioespacial e urbanização brasileira: escalas, vetores, ritmos e formas" (Processo FAPESP: 18/07701-8). Agradecemos ainda, as contribuições dos professores José Sobreiro Filho (UFPA) e Everaldo Santos Melazzo (UNESP) pela leitura e análises teórico-conceituais do trabalho. Os erros que porventura permaneçam são de nossa inteira responsabilidade.

\section{REFERÊNCIAS}

ABILIO, Ludmila Costhek. Uberização do trabalho: A subsunção real da viração, Blog da Boitempo, 2017. Disponível em: <https://blogdaboitempo.com.br/2017/02/22/uberizacao-do-trabalho-subsuncaorealda-viracao/>. Acesso em: 21 jan. 2020.

ALVES, Giovanni. Dimensões da Reestruturação Produtiva: ensaios de sociologia do trabalho. $2^{\underline{a}}$ edição, Londrina: Praxis; Bauru: Canal 6, 2007. 288 p. 
AMORIM, Daniela. Brasil tem recorde com $41,4 \%$ dos trabalhadores na informalidade. Estadão. São Paulo, 31 out. 2019. Disponível em: <https://economia.estadao.com.br/noticias/geral,brasil-tem-recorde-com-41-4dos-trabalhadores-na-informalidade,70003071073>. Acesso em: 02 mar. 2020.

ANTUNES, Ricardo. Adeus ao trabalho? Ensaio sobre as Metamorfoses e a Centralidade do Mundo do Trabalho. São Paulo: Cortez/ Unicamp, 2000. 200p.

. O privilégio da servidão. São Paulo: Boitempo, 2018.

ARAÚJO, Alison Cleiton de. Centralidade do trabalho: elementos críticos diante da crise contemporânea do capital. In: JORNADA INTERNACIONAL DE POLÍTICAS PÚBLICAS, 4, 2009, Maranhão. Anais ... Maranhão: Universidade Federal do Maranhão. Programa de Pós-Graduação em Políticas $\quad 2009 . \quad$ Públicas; Disponível em: http://www.joinpp.ufma.br/jornadas/joinpplV/eixos/2 transformacoes-do-mundo-do-

trabalho/centralidade-do-trabalho.pdf. Acesso em: 20 jan. 2020.

ARAÚJO, Tânia Bacelar de. Desenvolvimento regional brasileiro e políticas públicas federais no Governo Lula. In: SADER, Emir. (Org.). Lula e Dilma: 10 anos de Governos pós-neoliberais no Brasil. São Paulo: Boitempo, 2013. p. 157-171.

ARAÚJO, Ricardo. Informalidade sobe $15,44 \%$ no RN. Tribuna do Norte. Natal, 19 mai. 2019. Disponível em: <http://www.tribunadonorte.com.br/noticia/informalidade-sobe-15-88-no-rn/448431>. Acesso em: 22 jan. 2020.

BEE DELIVERY chega a 1 milhão de entregas e projeta voos internacionais. Economia, Mossoró Hoje, 07/06/2019. Disponível em: <https://mossorohoje.com.br/noticias/27848-bee-delivery-chega-a1-milhao-de-entregas-e-projeta-voos-internacionais >. Acesso em: 16 mar. 2020.

BEZERRA; Joel Medeiros, BATISTA; Rafael Oliveira, SILVA; Paulo César Moura da, MORAIS; Carlos Thiago da Silveira Lopes, FEITOSA; Alex Pinheiro. Aspectos econômicos e ambientais da exploração salineira no estado do Rio Grande do Norte. Engenharia Ambiental - Espírito Santo do Pinhal, v. 9, n. 2, p. 003-020, maio/jun. 2012.

BRASIL. Ministério do Trabalho e Emprego (MTE). O Cadastro Geral de Empregados e Desempregados (CAGED) 2019. Disponível em: http://trabalho.gov.br/trabalhador-caged. Acesso em: 22 jan. 2020.

CARVALHO, Isabela. Bee Delivery, startup criada em Mossoró, atinge 1 milhão de entregas. Starse, 29/08/2019. Disponível em: https://www.startse.com/noticia/empreendedores/startup-bee-delivery. Acesso: 16 mar. 2020.

CARLOS, Ana Fani Alexandri. A condição espacial. São Paulo: Contexto, 2011.

CAVALCANTE. José Luiz. A Lei de Terras de 1850: e a reafirmação do poder básico do Estado sobre a terra. Edição no 2 de junho de 2005. Disponível em: http://www.historica.arquivoestado.sp.gov.br/materias/anteriores/edicao02/materia02/LeideTerra.pdf.

Acesso em: 01 out. 2019.

CONSULTASOCIO. Cadastro de sócios de empresas brasileiras. Disponível em: https://www.consultasocio.com/. Acesso em: 22 abr. 2020.

CORREA, Roberto Lobato. Construindo o conceito de Cidade Média. In: SPOSITO, Maria Encarnação Beltrão (Orgs.). Cidades Médias: espaços em transição. São Paulo: Expressão Popular, 2007. p. 23-33.

DARDOT, Pierre; LAVAL, Christian. A nova razão do mundo: ensaio sobre a sociedade neoliberal. São Paulo: Boitempo, 2016.

DETRAN, Departamento de Trânsito do Rio Grande do Norte. Frota em tempo real - Detran-RN. Disponível em: http://www2.detran.rn.gov.br/externo/est tipo.asp?codcidade=1759. Acesso em: 09 abr. 2020.

DOMINGUES, Marcela Galizia. Análise dos impactos ambientais da instalação das unidades de bombeio de petróleo na área urbana de Mossoró-RN. (Dissertação de Mestrado em Geografia) Universidade Federal do Rio Grande do Norte. Centro de Ciências Humanas, Letras e Artes. Programa de Pós-Graduação em Geografia, Natal, 2014.

ELIAS, Denise; PEQUENO, Renato. Mossoró: O novo espaço da produção globalizada e aprofundamento das desigualdades socioespaciais. In: SPOSITO, Maria Encarnação Beltrão; ELIAS, Denise; SOARES, Beatriz Ribeiro. (Org). Agentes econômicos e reestruturação urbana e regional. Chillán e Marília. São Paulo: Outras Expressões, 2010. 
FERRARI, Terezinha. Fabricalização da Cidade e Ideologia da Circulação. São Paulo: Terceira Margem, 2005. 205 p.

FONTES, Virgínia. Capitalismo em tempos de uberização: do emprego ao trabalho. Marx e o $\begin{array}{lllllll}\text { Marxismo. } & \text { Revista semestral, } & \text { v. 5, n. } & \text { 8, jan/jun } 2017 .\end{array}$ http://niepmarx.blog.br/revistadoniep/index.php/MM/article/view/220. Acesso em: 21 mar. 2020.

GIL, A. C. Métodos e técnicas de pesquisa social. 6.ed. São Paulo: Atlas, 2011. $200 \mathrm{p}$

HARVEY, David. Condição pós-moderna: uma pesquisa sobre as origens da mudança cultural. 15. ed. tradução de Adail U̧birajara Sobral e Maria Stela Gonçalves. Rio de Janeiro: edições Loyola, 2006.

17 contradições e o fim do capitalismo. 1.ed. São Paulo: Boitempo, 2016.

IBGE- Instituto Brasileiro de Geografia e Estatística. Base cartográfica do IBGE, 2019.

IBGE - Cidades. Brasil em síntese. Disponível em: <https://cidades.ibge.gov.br/>. Acesso em: 10 jan. 2020.

Setor informal (ECINF- Setor informal da economia urbana). Disponível em: <https://www.ibge.gov.br/estatisticas/economicas/setor-informal.html>. Acesso em: 25 mar. 2020.

LEFEBVRE, Henri. La production de l'espace. 4 ed. Paris: Antrophos, 2000.

LIMA, Flávia. Emprego informal tira força da retomada. Folha de São Paulo. São Paulo, 26 mar. 2018. Disponível em: <https:/www1.folha.uol.com.br/mercado/2018/03/emprego-informal-tira-forca-da-retomada.shtml>. Acesso em: 10 de jan. 2020.

MARICATO, Ermínia. Para entender a crise urbana. São Paulo: Expressão Popular, 2015.

MARX, Karl; ENGELS, Friedrich. Manifesto Comunista. São Paulo: Boitempo, 1999.

2001.

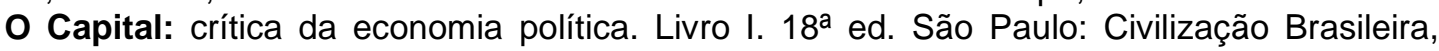

Grundrisse: manuscritos econômicos de 1857-1858 - esboços da crítica da economia política. São Paulo: Boitempo, 2011.

MATTOS, Carlos A. de. Modernización capitalista y transformación metropolitana en América Latina: cinco tendencias constitutivas. In: América Latina: cidade, campo e turismo. Amalia Inés Geraiges de Lemos Mónica Arroyo María Laura Silveira (Orgs.). Buenos Aires: CLACSO / São Paulo: Universidade de São Paulo, 2006. 360 p.

MÁXIMO, Welton. Entenda as principais mudanças com aprovação da reforma da previdência. Agência Brasil. Brasília, 23 out. 2019. Disponível em: <https://agenciabrasil.ebc.com.br/economia/noticia/2019-10/entendaprincipais-mudancas-com-aprovacao-da-reforma-da-previdencia>. Acesso em: 09 de abr. 2020.

MELAZZO, Everaldo Santos. Cidades médias e reprodução ampliada das desigualdades socioespaciais. In: XIII SEMINÁRIO INTERNACIONAL DA REDE IBEROAMERICANA DE INVESTIGADORES - RII, 13, 2014, Salvador. Anais ... Salvador, 2014. v. 1. p. 1-15. Disponível em: <http://www.rii.sei.ba.gov.br/anais_xiii/gt6/GT6_EVERALDO.pdf>. Acesso em: 02 de abr. de 2020.

MÉSZÁROS, István. Para além do capital: rumo a uma teoria da transição. São Paulo: Boitempo, 2011.

MOURA, Marcelo. Nação delivery: os aplicativos cruzam a fronteira da alimentação e interferem em outras indústrias. O consumo (de qualquer coisa) nunca mais será o mesmo. Época Negócios, $n$. 156, fev. 2020. p. 60-83.

NERI, Marcelo. A escalada da desigualdade: qual foi o impacto da crise sobre a desigualdade, o crescimento e a pobreza? Fundação Getúlio Vargas, agosto de 2019. Disponível em: $<$ https://cps.fgv.br/desigualdade> Acesso em: 20 fev. 2020.

NITAHARA. Akemi. Informalidade no mercado de trabalho é recorde, aponta IBGE. AGÊNCIA BRASIL, Rio de Janeiro, 31 out. 2019. Disponível em: $<$ http://agenciabrasil.ebc.com.br/economia/noticia/2019-10/informalidade-no-mercado-de-trabalho-erecorde-aponta-ibge >. Acesso em: 21 de jan. 2020.

OLIVEIRA, Francisco. Crítica à razão dualista/ o Ornitorrinco. São Paulo: Boitempo, 2003.

OXFAM BRASIL. A distância que nos une: um retrato das desigualdades brasileiras. 25 de setembro de 2017. Disponível em: <https://www.oxfam.org.br/a-distancia-que-nos-une>. Acesso em: 16 set. 2018.

POCHMANN, Márcio. 0 mito da grande classe média: capitalismo e estrutura social. São Paulo: Boitempo, 2014. 
Desempenho econômico conjuntural e a situação recente do trabalho no Brasil. Revista do

Núcleo de Estudos de Economia Catarinense, v. 7, n. 13, p. 12-28, 2018.

PONTES, Beatriz Maria Soares. Contradições, mudanças e permanências nos espaços urbanos nordestinos. In: DIAS, Patrícia Chame; SANTOS, Janio. (Org.). Cidades Médias e Pequenas: Contradições, Mudanças e permanências nos Espaços Urbanos. 1ed.Salvador: SEI, 2012, v., p. 19-46.

ROCHA, Aristotelina Pereira Barreto. Expansão Urbana de Mossoró (período de 1980 a 2004): geografia dinâmica e reestruturação do território. Natal: EDUFRN, 2005.

RUBIN, Isaak Illich. A teoria marxista do valor. São Paulo: Brasiliense, 1980.

SABINO, André M..; ABÍLIO, Ludmila C. Uberização: o empreendedorismo como novo nome para a exploração. Revista Jurídica Trabalho e Desenvolvimento Humano, Campinas, v. 2, n. 2, p. 109135, 2019. https://doi.org/10.33239/rtdh.v2i2.53

SANTOS, Milton. Por uma geografia nova. São Paulo: Hucitec, 1978.

. A natureza do espaço: técnica e tempo; razão e emoção. São Paulo: HUCITEC, 1996.

Por uma outra globalização: do pensamento único à consciência universal. 10. ed. Rio de Janeiro: Record, 2003. 174 p.

. A Urbanização Brasileira. São Paulo: Editora da Universidade de São Paulo, 2008.

SILVA, Ilse Gomes da. A agenda conservadora assume o centro da cena política no Brasil. Lutas Sociais, São Paulo, v. 20, n. 36, p. 140- 150, jan./jun. 2016.

SILVEIRA, Maria Laura. Pensando o fenômeno urbano contemporâneo. In: DIAS, Patrícia Chame; BRANDÃO, Paulo Roberto Baqueiro. (Org.). Cidades médias e pequenas: dinâmicas espaciais, contradições e perspectivas na relação cidade-campo. 9 ed. Salvador: Publicações SEI (Superintendência de Estudos Econômicos e Sociais da Bahia), 2015, v. 99, p. 171-183.

SINGER, Paul. A economia dos serviços. Estudos CEBRAP, São Paulo, n. 24, p. 128-135, 1979.

SINGER, André. Os sentidos do Lulismo. São Paulo: Companhia das Letras, 2012.

Por uma frente ampla, democrática e republicana. In: Jinkings, Ivana; Doria, Kim; Cleto, Murilo (orgs.) Por que gritamos golpe? Para entender o impeachment e a crise. São Paulo: Boitempo, 2016.

SLEE, Tom. Uberização: a nova onda do trabalho precarizado. São Paulo: Elefante, 2017.

SMITH, Neil. Desenvolvimento desigual. Rio de Janeiro: Bertrand, 1988.

Contornos de uma política espacializada: veículos dos sem teto e produção da escala geográfica. In: ARANTES, Antonio A. (org.) O espaço da diferença. Campinas: Papirus, 2000. p. $132-175$

SOARES, Jamilson Azevedo. A juventude nos enredos da cidade, da cultura e do lazer: panis et circenses no 'país de Mossoró'? Tese (Doutorado em Geografia) - Universidade Federal de Pernambuco. Centro de Filosofia e Ciências Humanas. Programa de Pós-Graduação em Geografia, Recife, 2015. 270 p.

SOJA, Edward W. Geografias pós-modernas: a reafirmação do espaço na teoria social crítica. Rio de Janeiro: Zahar, 1993 [1989].

Tensiones urbanas: globalización, reestructuración económica e trasnsición postmetropolitana. BENACH, Núria; ALBET, Abel. Edward W. Soja. A perspectiva postmoderna de um geográfico crítico radical. Barcelona: Icária, 2010. p. 210-224.

SOUZA, Jessé. Os batalhadores brasileiros: nova classe média ou nova classe trabalhadora? 2 ed. Belo Horizonte: Editora UFMG, 2012.

SPOSITO, Maria Encarnação Beltrão. Cidades médias: reestruturação das cidades e reestruturação urbana. In: 2007, p. 233-253. (Org.). Cidades médias: espaços em transição. São Paulo: Expressão Popular,

O desafio para o estudo das cidades médias. XI Seminário Internacional da Redlberoamericana de Investigadores sobre Globalización y Território (RII). Mendoza, 2010. Anais... Mendoza, Argentina, 2010, p. 1-18.

STANDING, Guy. 0 precariado: a nova classe perigosa; Tradução Cristina Antunes. 1. ed.; 2. reimp. Belo Horizonte: Autêntica Editora, 2015. 
TELLES, Vera da Silva. Mutações do trabalho e experiência urbana. Tempo Social: Revista de Sociologia da USP, São Paulo, v. 18, n. ju 2006, p. 173-195. https://doi.org/10.1590/S010320702006000100010

TORRE, Bruna Della. Adorno e o novo milênio: notas sobre a indústria cultural e capitalismo de plataforma. In: COLÓQUIO INTERNACIONAL MARX E O MARXISMO: MARXISMO SEM TABUS: ENFRENTANDO OPRESSÕES, 2019, Niterói/RJ. Anais ... p. 1-21. Disponível em: <http://www.niepmarx.blog.br/MM2019/Trabalhos\%20aprovados/MC40/MC403.pdf> Acesso em: 09 Abr. 2020.

VASAPOLLO, Luciano. Por uma política de classe: uma interpretação marxista do mundo globalizado. Tradução de Juliana Coli. 1ํ Ed. São Paulo: Expressão Popular, 2007.

Recebido em: 02/05/2020

Aceito para publicação em: 02/10/2021 